\title{
HUNG OUT TO DRY? QUESTIONING THE LEGALITY OF MINNIE DEAN'S 1895 TRIAL AND EXECUTION
}

\author{
Sophie Davis*
}

In 1895 Minnie Dean became the only New Zealand woman to receive the death penalty. She was found guilty in the Invercargill Supreme Court of the murder of Dorothy Edith Carter, a child she had recently adopted, who was found buried in her garden alongside two other infants. Branded a vindictive baby-farmer, Minnie Dean was widely condemned by the New Zealand press and public during the four months between her arrest and execution. This article will assess whether Minnie Dean was afforded a fair criminal trial and sentencing. From a 21 st century perspective, it can appear that Minnie's fate was inevitable from the time of her arrest and that her trial was merely a formality. Despite Minnie's often harsh treatment, this article will argue that against 1895 legal standards, correct criminal procedure was generally followed. However, when comparing Minnie Dean's trial and sentencing with contemporaneous murder trials, it is evident that she received no procedural clemency.

\section{INTRODUCTION}

Williamina "Minnie" Dean has earned the infamous place in New Zealand history as the only woman to have received the death penalty. In 1895 she was found guilty in the Invercargill Supreme Court of the murder of an 11-month-old child, Dorothy Edith Carter. The Crown argued that Minnie had administered an overdose of laudanum to Dorothy, whom she had adopted two days prior, while on the train to adopt another infant, Eva Hornsby. Minnie was alleged to have then suffocated Eva and buried both of the children in her garden. Minnie's arrest occurred at a time when dramatic accounts of infanticide in Britain and Australia were being reported in the newspapers. During the four months between her arrest and execution, Minnie was widely condemned by the New Zealand public, who were horrified at the prospect of such a social evil being present in the young colony.

* Article submitted as part of the LLB(Hons) programme at Victoria University of Wellington. I am most grateful for the guidance of my supervisor, Dr Grant Morris. 
The question of whether Minnie intentionally killed the children, or if instead their deaths were an accident, has been broached by a number of historians, most notably by Lynley Hood in her 1994 biography Minnie Dean: Her Life and Crimes. ${ }^{1}$ This article does not intend to reiterate this discussion, but rather inquire from a legal perspective into whether Minnie was afforded a fair trial and sentence. From a 21 st century standard, it can appear that Minnie's fate was determined from the moment of her arrest. She was publicly labelled a murderess during the coroners' inquests, vilified by the press, tried before a jury of men drawn from the hostile local community, faced multiple hurdles to appear before an appellate court and had her trial presided over by a judge who strongly warned the jury against finding a manslaughter verdict. Despite these discrepancies, when assessing Minnie's trial strictly against 19th century criminal procedure, due process was generally followed. What is significant about Minnie's trial is that unlike the accused in other 19th century murder proceedings, she was afforded no procedural clemency. Studying Minnie Dean's trial is an important historiographical topic not just because of the outcome, but because it exposes the subjectivity and elitism inherent within 19th century New Zealand criminal proceedings.

\section{METHODOLOGY}

In determining whether Minnie Dean was granted due process, this article will measure her trial against criminal procedure as it was in 1895. Criminal procedure underwent a series of reforms in the 1890s. Most significant was the introduction of the Criminal Code Act 1893 which standardised and simplified the law. ${ }^{2}$ A number of criminal procedures required discretionary decisions, so in order to establish general practice other 19th century trials will be used as comparisons. The main comparator case will be the trial of Thomas Hall, an affluent Timaru businessman who in 1886 was found guilty of poisoning his wife. This conviction led to the exhumation of his father-in-law Captain Cain, who had died from a mysterious illness earlier that year. Captain Cain showed signs of antimony poisoning and Hall was charged with his murder. After a trial in Dunedin, Thomas Hall was found guilty and was set to receive the death penalty, but had his sentence quashed in the Court of Appeal due to an evidential issue. ${ }^{3}$

\section{MINNIE DEAN'S BACKGROUND AND ARREST}

Minnie was born Williamina McCulloch on 2 September 1844 in West Greenock, Scotland. Little is known about how Minnie came to arrive in Invercargill with two young daughters in the early 1860s. She claimed to be a widow whose husband had died in Tasmania, yet no evidence of

1 Lynley Hood Minnie Dean: Her Life and Crimes (Penguin Books, Auckland, 1994).

2 ID Campbell "Criminal Law" in JL Robson (ed) New Zealand: The Development of its Laws and Constitution (2nd ed, Stevens \& Sons, London, 1967) 361 at 365.

3 Brian O'Brien "Hall, Thomas" (25 March 2014) Te Ara: The Encyclopedia of New Zealand <www.teara.govt.nz>. 
her marriage has been found. ${ }^{4}$ In 1872 Minnie married an innkeeper named Charles Dean who lived in Etal Creek, Southland. In 1880, with her daughters married, Minnie adopted her first child, fiveyear-old Margaret Cameron. Charles subsequently became a farmer but when the land boom collapsed in 1884 , he soon became bankrupt. In 1887 the Deans moved to a property called The Larches in Winton, a small town $30 \mathrm{~km}$ north of Invercargill, where Charles worked as a farmhand. In 1889, faced with financial difficulties, Minnie began to place adoption advertisements in the local newspapers, calling herself "a respectable married woman with no young children" who wanted "a baby to nurse, or one or two young children to bring up, or a baby to adopt". 5

In colonial New Zealand, traditional Victorian values prevailed and many unmarried mothers were shunned from society, resulting in considerable demand for discreet child-minding. ${ }^{6}$ During the mid-19th century, non-institutional paid childcare came under scrutiny in New Zealand as the colony followed dramatic accounts of baby-farmers in Britain and Australia. ${ }^{7}$ The term "babyfarming" was first used in the British Medical Journal (BMJ) in 1867 in a report detailing how a woman's four children died in the care of the same hired foster mother. The article "insinuated that the mother had turned her children over to the 'baby-farmer' with the implicit understanding that they would be neglected until they died". ${ }^{8}$ In a series of sensationalist pieces, it was argued that many baby-farmers committed serial infanticide. ${ }^{9}$ These articles brought the term into widespread use and baby-farming became associated with women who received infants to nurse for a monetary payment. ${ }^{10}$ The expression was "deliberately pejorative as it emphasised the economic connotations of the arrangement". ${ }^{11}$ At a time when Western ideals of maternity and domesticity were paramount, the concept of foster mothers as economic rather than moral agents became increasingly abhorrent. ${ }^{12}$ A number of child abuse cases were uncovered in New Zealand during the 1880 s.

4 Lynley Hood "Dean, Williamina" (7 June 2013) Te Ara: The Encyclopedia of New Zealand <www.teara.govt.nz>.

5 Southland Times (Invercargill, 17 April 1889) at 3.

6 Hood, above n 4.

7 Bronwyn Dalley "Criminal Conversations: Infanticide, Gender and Sexuality in Nineteenth Century New Zealand" in Caroline Daley and Deborah Montgomerie (eds) The Gendered Kiwi (Auckland University Press, Auckland, 1999) 63 at 76.

8 Ruth Ellen Homrighaus "Baby Farming: The Care of Illegitimate Children in England, 1860-1943" (revised ed, PhD Dissertation, University of North Carolina, 2010) at 3.

9 At 3

10 At 3 .

11 Debra Powell "The Ogress, the Innocent and the Madman: Narrative and Gender in Child Homicide Trials in New Zealand, 1870 - 1925" (PhD Thesis, University of Waikato, 2013) at 279.

12 At 279 
These were widely reported in the newspapers, reinforcing the stereotypical imaginings of babyfarmers. ${ }^{13}$

During the early 1890s Minnie steadily took on more infants and she was soon caring for up to nine children at any one time. She began to attract police suspicion and following the deaths of two children due to illness, rumours about her being a baby-farmer spread. ${ }^{14}$ Amid growing anxiety about infanticide, the Government passed the Infant Life Protection Act 1893. The Act required people who cared for one or more children under the age of two for more than three consecutive days to register themselves and their homes. ${ }^{15}$ The police had the power to inspect the registered houses and the infants living there. ${ }^{16}$ Minnie did not register and with the police intensifying their surveillance she became increasingly secretive, carrying out most of her dealings under assumed names. ${ }^{17}$

The events that led to Minnie Dean's arrest occurred over the course of a few days. On Tuesday 30 April 1895 Minnie travelled by train to Bluff, where she collected an eleven-month-old child named Dorothy Edith Carter. After returning home for two days Minnie had arranged to collect a one-month-old baby, Eva Hornsby, from Milburn. She took Dorothy with her and planned to break the train journey with a night in Lumsden. To ensure a peaceful journey she gave Dorothy two doses of laudanum, an opiate commonly used in the 1800 s to soothe children. ${ }^{18}$ While on the train Minnie discovered that Dorothy had died from what was subsequently established to be an overdose of laudanum. In Minnie's last statement, written shortly before her execution, she described how she did not know what to do and "bereft of reason" she hid the child in her hat box and rushed to her hotel in Lumsden. In her room she "at once took the child out of the box and no sleep visited [her] eyes that night". 19 The following day Minnie headed to Milburn to collect Eva from her grandmother, Jane Hornsby, as if nothing had happened. She was later observed by a newsagent boarding the train in Milburn with a baby, however by the time she arrived at the station in Winton she was carrying only her hatbox.

Alerted by the station master, the police traced Jane Hornsby and discovered that she had handed over her granddaughter to Minnie Dean. The police took Jane with them to The Larches

13 At 290

14 Hood, above n 4.

15 Section 5.

16 Section 8.

17 Hood, above $\mathrm{n} 4$.

18 Hood, above n 4.

19 "Minnie Dean's Last Statement" in Ken Catran Hanlon: A Casebook (BCNZ Enterprises, Auckland, 1985) at 171 . 
where they found Eva's clothes. Minnie was arrested and charged with infanticide. Policemen began to search along the railway tracks and at The Larches. Two days later the police found the corpses of two female infants buried in the garden. Charles Dean was immediately arrested. ${ }^{20}$ Subsequent digging revealed the skeleton of a boy thought to be around three-years old, close to where the other bodies were discovered..$^{21}$ Following Minnie Dean's arrest, Alfred Hanlon, a Dunedin barrister, took on the role of her defence counsel.

\section{PRE-TRIAL PROCEEDINGS}

\section{A Coroners' Inquests}

\section{Legal procedure}

The coroner is one of the oldest offices known to English law and by 1500 its main function was to hold inquests into the manner of deaths - normally homicides and deaths by misadventure. ${ }^{22}$ The duties of 19th century New Zealand coroners were regulated by the Coroners Act 1867, per its amendments in 1885 and $1888 .{ }^{23}$ Upon notice of a death the local coroner was required to summon a jury of no more than six local men to hear an inquest. ${ }^{24}$ The general rules of evidence applied at inquests, with witnesses and medical practitioners being called on behalf of the Crown and the accused. $^{25}$ The jury was expected to reach a verdict on the death and model statements were supplied by the Department of Justice. For an inquisition of murder, the jury was directed to expressly state "and so the said A.B. then and there feloniously killed and murdered the said C.D. against the peace of our said Lady the Queen her crown and dignity". ${ }^{26}$

\section{Application to Minnie Dean}

Following Minnie's arrest, three separate inquests were held before juries of local men. The first was on the body of Dorothy Edith Carter. Evidence was produced to show that opium was found in her body, administered through laudanum. The jury concluded that Dorothy died on 2 May, between Winton and Lumsden, through poison administered by Minnie Dean. ${ }^{27}$ The second inquest was on Eva Hornsby. Doctors gave evidence that the cause of death was asphyxia. There were small marks

20 "Alleged Infanticide" Otago Daily Times (Dunedin, 13 May 1895) at 3.

21 "Further Particulars - The Skeleton of a Child Unearthed" Otago Witness (Dunedin, 16 May 1895) at 28.

22 Law Commission Coroners: A Review (NZLC PP36, 1999) at 32.

23 William Reeve Haselden New Zealand Justice of the Peace (Government Printer, Wellington, 1895) at 285.

24 Coroners Act 1867, s 10; Coroners Amendment Act 1885, s 2.

25 Haselden, above n 23, at 297.

26 At $205-306$.

27 "The Verdicts" Otago Witness (Dunedin, 6 June 1895) at 21. 
on opposite sides of her skull which were probably caused by pressure or force to her head. ${ }^{28}$ The jury believed that Eva was wilfully murdered on or about 3 May. However, the foreman declined to state who the jury believed was responsible. ${ }^{29}$ The final inquest was on the skeleton. The jury returned with the verdict that although there was no evidence of the time, cause and place of death, they were strongly of the opinion that the skeleton was Willie Phelan, a child who had disappeared under Minnie's care two years earlier. ${ }^{30}$

The inquests in Minnie Dean's case highlight the power wielded by 19th century coroners' courts, with there being few restraints on the evidence and the juries' conclusions. However, this power was not always exercised. During the inquests in the murder trials of Thomas Hall (1886) and Louis Chemis (1889) the juries declined to name the person they believed to be responsible, as to do so would prejudice the right of the suspect to a fair trial. ${ }^{31}$ Lynley Hood argued that the inquests "allowed the police to convey to the public and the press that Minnie Dean was engaged in a largescale, cold-blooded, mercenary scheme of systematic, premeditated murder". ${ }^{32}$ There is some validity to this claim as the three inquests were extensively reported by the press. While only officially named as Dorothy's murderer, Minnie was clearly linked to the murders of Eva and Willie, portraying her as a multiple murderer before her trial had even begun. However, Hood's argument is likely too idealistic. Identifying the murderer was what the inquest juries were expressly expected to do, despite other inquest juries declining to do so. While it can appear unjust that the coroners' inquests were so widely reported, there was nothing procedurally invalid about the process. If anything, pre-trial publicity about an accused can be more widespread today due to often extensive media coverage around murder trials.

\section{B Magisterial Hearing}

Minnie Dean's magisterial hearing took place over three days from 6 June 1895. The Magistrate would decide if there was enough evidence to bring Minnie to trial. Similar evidence to the inquests was heard, covering Minnie's journey along the railway tracks, her dealings with pregnant mothers for children, medical evidence about the children's deaths and that laudanum had been found in her home. ${ }^{33}$ Despite Alfred Hanlon exposing some flaws in the Crown's arguments, the overall case against Minnie remained strong. Hanlon intimated that he would reserve his defence for the

28 At 21 .

29 At 21 .

30 "Winton Baby-Farming Case" Otago Daily Times (Dunedin, 11 June 1895) at 6.

31 Hood, above n 1, at 133.

32 At 157

33 "Winton Baby-Farming Cases" Otago Witness (Dunedin, 13 June 1895) at 19. 
Supreme Court and Minnie Dean was committed for trial. ${ }^{34}$ The Magistrate accepted that there was no evidence Charles Dean knew of his wife's actions and he was duly discharged. ${ }^{35}$

\section{THE SUPREME COURT TRIAL}

\section{A Trial Publicity}

Minnie Dean's trial opened on the morning of Tuesday 18 June 1895 before Williams J in the Invercargill Supreme Court. ${ }^{36}$ Despite no official record of court proceedings, extensive documentation remains due to the Judge's detailed notes and the local press coverage, which reported virtually every detail of the four-day trial. ${ }^{37}$ Such in-depth newspaper coverage of a highprofile trial was not unusual, with court reporting becoming part of the "new journalism" of the last quarter of the 19th century. This was a sensationalist literary style that largely relied on personal stories to map out social unrest and scandal. ${ }^{38}$ Newspaper reporters used "vivid language, evocative detail, accounts of crowded courtrooms and sensational subjects" to magnify the drama of criminal trials, while simultaneously decreeing the moral lessons to be learnt from them. ${ }^{39}$ This style of journalism was evident during Minnie's trial as reporters recounted in detail the scenes from the packed public gallery. ${ }^{40}$ Minnie was described as being "perfectly calm in her demeanour ... and gave no visible signs of being much concerned about her position". ${ }^{41}$ Minnie Dean was charged with the murder of Dorothy Edith Carter. The Crown planned to follow with the other charges if Minnie was found not guilty. ${ }^{42}$

\section{B Trial Location}

\section{Legal procedure}

The Criminal Code Act 1893 enabled a Supreme Court judge, if it appeared "expedient for the ends of justice" to make an order for a trial to be held in a different location from the court the accused would ordinarily be tried at. ${ }^{43}$ The judge could make "an order subject to conditions as to

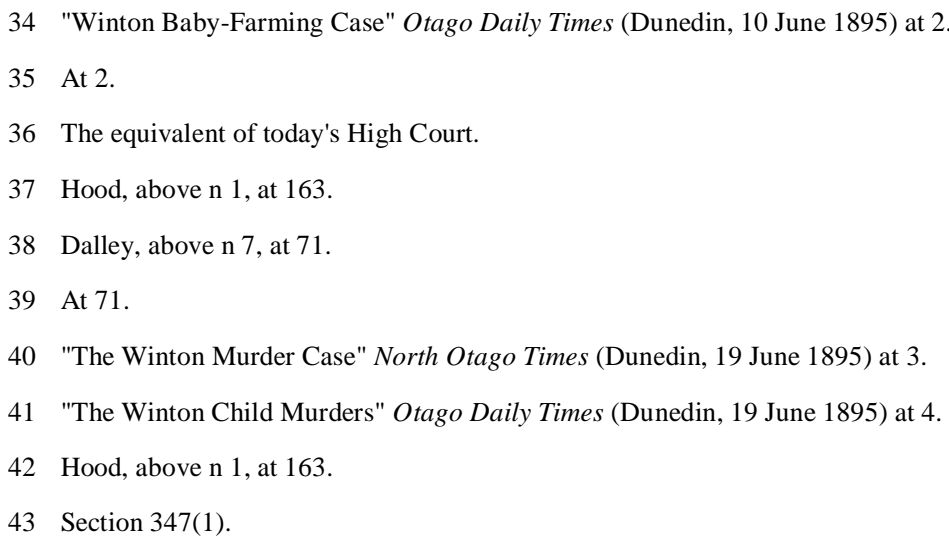


bail, the payment of costs for the prosecutor and witnesses ... and of the removal of the person charged, and as to any other matter or thing whatsoever as such Judge may, in his discretion, impose". ${ }^{44}$

In England by the mid-19th century, it was open for the King's Bench to order a change in venue when there was extreme prejudice against the accused. There were doubts though as to the scope of the jurisdiction and applications were sparingly granted. ${ }^{45}$ In the notable 1856 trial of William Palmer, an English doctor who was charged with poisoning his friend, it was felt that local prejudice would be so strong against Palmer in Staffordshire, that Parliament hastily enacted a Bill enabling offenders to be tried at the Central Criminal Court in London. ${ }^{46}$

In New Zealand, Thomas Hall was granted two changes in trial location. During the 1886 magisterial hearing for the poisoning of his wife, Hall's lawyer successfully applied to move the trial to Christchurch, arguing that feeling in Timaru was so strong against Hall that the public "would hang the accused even without a trial". ${ }^{47}$ When Hall was then charged with the murder of Captain Cain, his lawyer pleaded for Hall not to be committed in Christchurch. Having already gone through a trial in that city, it was argued that the public would be biased against Hall. A second change of venue was granted and Hall was duly committed in Dunedin before Williams J, the same judge who would preside over Minnie Dean's trial. ${ }^{48}$

\section{Application to Minnie Dean}

According to the Hanlon family, Alfred Hanlon unsuccessfully requested a change of trial venue in chambers soon after Minnie's magisterial hearing. Hanlon wanted Minnie's trial to be held in Christchurch, largely so she could escape the Invercargill public. ${ }^{49}$ There are a number of factors which suggest that there was extreme local prejudice against Minnie, to the extent that her trial should have changed location. Most significant was the hostile coverage about Minnie's case by the local press from the moment of her arrest. The details of the coroners' inquests and magisterial hearings were extensively reported. ${ }^{50}$ Beyond the courts, the press clambered to get exclusives

44 Section 347(2).

45 David Bentley English Criminal Justice in the 19th Century (The Hambledon Press, London, 1998 ) at 47.

46 George Knott Trial of William Palmer (William Hodge \& Company, Edinburgh, 1912) at 12.

47 "The Hall Case" Timaru Herald (Timaru, 21 September 1886) at 3.

48 Hood, above n 1 , at 150.

49 At 150 .

50 See for example "The Child Murder Case" West Coast Times (Hokitika, 5 June 1895) at 4; "The Dean Murders" Thames Star (Thames, 5 June 1895) at 3;"The Winton Sensation" Wanganui Herald (Wanganui, 5 June 1895) at 2; "The Verdicts" Otago Witness (Dunedin, 6 June 1895) at 21; "Winton Baby-Farming Case" Otago Daily Times (Dunedin, 8 June 1895) at 6; and "The Winton Baby-Farming Case" New Zealand Herald (Auckland, 10 June 1895) at 5. 
about the sensational case, with lurid and damning details about the Deans filling the papers. Many of these accounts were factually incorrect, for example it was reported that Charles had met Minnie at the station and carried home a large parcel, commenting to a bystander, "My wife's got a bargain this time" ${ }^{51}$ It was also said that just as the police arrived, Charles rode off with a mysterious sack on the saddle in front him, suggesting that even more bodies were being hidden. ${ }^{52}$ The press soon began conducting their own investigations, which depicted the Deans in a disparaging light. For example, the West Coast Times printed a "special" report in which The Larches was portrayed as "a wretched hovel" with it being "difficult to conceive how any mother with the slightest spark of feeling could consent to her child being brought up in such an environment". 53

Public indignation also manifested outside the pages of newspapers. On the first day of the inquest, the police could have taken Minnie from the Milton railway station to the court house by carriage, but instead escorted her by foot through the jeering crowd that lined the half-mile route. ${ }^{54}$ When Minnie left later that day, the biggest crowd ever assembled at the station pressed around the compartment window, and some people even climbed aboard and fought for standing room in the narrow corridor. ${ }^{55}$ The image of Minnie Dean as a monstrous baby-farmer was further exacerbated during the trial, with dolls in miniature hatboxes reputedly being sold as souvenirs outside the courtroom. 56

Despite the evidence of strong local hostility towards Minnie Dean, this did not necessarily warrant a change in trial location. Moving the location may not have even resulted in a substantially fairer trial as the sensational case was being extensively reported around New Zealand. While negative opinion was likely stronger in Southland, this was not something that could simply be ameliorated by a change in location. In comparison, public prejudice in the Thomas Hall case was arguably more particular to the location, as he was well-known mainly in Timaru, and his case did not tap into the same widespread public hysteria as Minnie Dean's. A change in location was ultimately a discretionary decision for the Judge. There were also issues of cost and the practicality of transporting witnesses to another town to be considered. While it is certainly questionable that Thomas Hall was successful in having his trial location changed, this does not in and of itself mean that due process was not followed in Minnie Dean's trial.

51 Hood, above $\mathrm{n} 1$, at 130

52 At 130 .

53 "The Child Murder Cases" West Coast Times (Hokitika, 1 June 1895) at 4

54 Hood, above $\mathrm{n} 1$, at 136 .

55 At 136.

56 Carl Walrond "Crime and the media - Popular culture and mythology" (16 November 2012) Te Ara: The Encyclopedia of New Zealand <www.teara.govt.nz〉. 


\section{The Jury}

\section{Legal procedure}

The use of a jury in trials on indictment has been a feature of criminal law procedure for centuries. The jury is proclaimed as being a constitutional safeguard as it is a "means of maintaining public confidence, and public interest, in the administration of the common law". ${ }^{57}$ The jury is commonly seen as having been introduced into England by the Normans. However, it appears to have existed prior to that in various parts of Europe. ${ }^{58}$ By the late 14th century, juries largely resembled a body of witnesses, as they were there to provide information to the judge from their own knowledge, rather than decide on facts. ${ }^{59}$ As the practice of calling witnesses grew, it gradually became less important for the jury to have actual knowledge of the case. ${ }^{60}$ By the 19th century jurors were "expected to be entirely independent and have no prior knowledge". ${ }^{61}$ New Zealand adopted the English jury structure, with the Supreme Court Ordinance of 1841 providing for a criminal jury of 12 men for all trials to be heard on indictment. ${ }^{62}$

Today, one of the most fundamental values of the jury system is its democratic nature as it allows "members of the community direct participation in the criminal justice system". ${ }^{63} \mathrm{By}$ contrast, 19th century juries were far from representative. Eligibility for jury service in the Supreme Court was initially restricted to male residents between 21 and 60 years of age who held an estate in fee simple in land or tenements. From 1841, a wide range of political, legal, civil service and essential industries personnel were either disqualified or excused from jury service. ${ }^{64}$ Women were excluded from juries until 1942, and even then only women between the ages of 25 and 60 who volunteered were allowed. It took until 1976 for women to be eligible on the same terms as men. ${ }^{65}$ Māori were also excluded from the common jury and it was not until 1962, with the abolition of the last of the mixed-race jury provisions, that Māori could sit on juries for trials of non-Māori. ${ }^{66}$

57 Francis Boyd Adams Criminal Law and Practice in New Zealand (2nd ed, Sweet \& Maxwell, Wellington, 1971) at 744-745.

58 Law Commission Juries in Criminal Trials: Part One (NZLC PP32, 1998) at 1.

59 Jeremy Finn "The English Heritage" in Peter Spiller, Jeremy Finn and Richard Boast (eds) A New Zealand Legal History (2nd ed, Brookers, Wellington, 2001) 1 at 11.

60 At 11 .

61 Law Commission, above $\mathrm{n} 58$, at 1.

62 Supreme Court Ordinance 18415 Vict 1, cl 19.

63 Law Commission, above n 58, at 1.

64 Neil Cameron, Susan Potter, and Warren Young "The New Zealand Jury" (1999) 62 LCP 103 at 105-106.

65 At 105

66 Juries Amendment Act 1962, s 2. 


\section{Application to Minnie Dean}

On the opening morning of Minnie Dean's trial, a jury was drawn from a roll containing the names of eligible men between the ages of 21 and 60 living within a 20-mile radius of Invercargill. Ten potential jurors were challenged by Hanlon and nine were challenged by the Crown. ${ }^{67}$ The resulting 12 men were sworn in as jurors, before being named in the newspaper the following day. From modern standards, the fact that a jury of 12 men were responsible for Minnie's fate appears far from fair and representative. This was a case connected with childcare, an issue which in the 19th century was largely deemed a female and domestic matter. There is the strong possibility that female jurors, in particular mothers, would have judged Minnie harsher than an all-male jury. Yet the jury would have at least reflected a jury of Minnie's peers. Nevertheless, when assessing the jury selection against 1895 legal standards, due process appears to have been followed.

When Thomas Hall was tried for the murder of Captain Cain, he was granted a special jury. ${ }^{68}$ Under the Juries Act 1880, any party in a case before the Supreme Court could apply for a special jury. Each court would have a roll book of professional men with occupations such as "esquires, gentlemen, merchants, managers of banks, civil engineers, and architects". ${ }^{69}$ The Supreme Court had a general discretion in applications for trials by special jury as there were no express limitations to the class of cases for which they could be used. ${ }^{70}$ Despite there being no criteria, in the Hall trial the Judge remarked that if "criminal cases were to be tried by special juries at all, this was one of the kind of cases the Legislature contemplated". ${ }^{71}$ A special jury would not have been beneficial to Minnie Dean as the jury's composition would have had even less resemblance to a jury of her peers than the common jury did. ${ }^{72}$ Yet the provision highlights how for certain affluent members of society there was the ability to have a jury of men from similar backgrounds, who may have been more sympathetic to their cause.

\section{The Crown's Case}

The Crown prosecutor opened his case by outlining how the jury would need to decide two questions from the evidence adduced at trial. Was the death of Dorothy Edith Carter caused by the accused, and if so, was the jury satisfied that the death was wilfully and intentionally caused? If these questions were satisfied beyond reasonable doubt, the jury's duty was to find Minnie Dean

$67 R v$ Dean SC Invercargill, 18 June 1895, reported in Otago Daily Times (Dunedin, 19 June 1895) 4 at 4.

68 Hood, above n 1, at 164

69 Juries Act 1880, s 35.

70 BJ Cameron "The Judicial System" in JL Robson (ed) New Zealand: The Development of its Laws and Constitution (Stevens \& Sons, London, 1967) 70 at 97.

71 "Supreme Court in Session" Southland Times (Invercargill, 5 January 1887) at 2.

72 Hood, above n 1, at 164. 
guilty of murder. ${ }^{73}$ The prosecutor stated that it was unnecessary for the Crown to prove motive, but if the crime was committed the motive would be perfectly obvious: Minnie Dean wanted to get rid of the expense of maintaining the child and to avoid a penalty under the Life Protection Act. ${ }^{74}$ The Crown called a succession of witnesses, most having been heard at the inquests and the magisterial hearing. The witnesses testified to Minnie buying laudanum in Bluff and collecting Dorothy under a pseudonym. In Hanlon's cross-examination of Louisa Cox, the go-between for Dorothy's mother, Louisa revealed that she had never given Minnie any money for Dorothy, although they had made an arrangement for money in June. ${ }^{75}$ Further evidence was given detailing Minnie's actions over the following days and the disappearance of earlier children under Minnie's care. By the end of the Crown's case, 47 witnesses had taken the stand and 35 exhibits, including press advertisements, letters, medicine bottles and train tickets had been produced. ${ }^{76}$

\section{E Appealing a Point of Law}

\section{Legal procedure}

Under the early English common law, there was no procedure that could be described as a right of appeal in criminal cases. Instead there was a practice under which the trial judge might, where difficulty arose, refer to other judges for their opinion. ${ }^{77}$ English criminal law developed in this manner and eventually under the Crown Cases Act 1848, a new appellate court was established. This court could only deal with questions of law and only when reserved for consideration by the trial judge. ${ }^{78}$ Substantially similar provisions were enacted in New Zealand through the Court of Appeal Act 1862. ${ }^{79}$ There was no remedy if the judge refused to reserve a question and any appeal would be heard by a sitting of all available Supreme Court judges, including the judge being challenged ${ }^{80}$ After the 1893 reforms, there was the additional option for a judge to take note of an objection, unless they considered it frivolous. ${ }^{81}$ The concerned party could then apply for leave

$73 R v$ Dean, above $\mathrm{n} 67$, at 4.

74 At 4.

75 At 4.

76 Hood, above n 1, at 173.

77 Adams, above n 57, at 835.

78 At 826.

79 Section 69.

80 Jeremy Finn "John James Meikle and the Problem of the Wrongly Convicted: An Enquiry into the History of Criminal Appeals in New Zealand" (2010) 41 VUWLR 519 at 520.

81 Criminal Code Act 1893, s 412(3). 
from the Attorney-General to appeal to the Court of Appeal. ${ }^{82}$ Appeals could not be made as of right until 1945, 38 years after England. ${ }^{83}$

\section{Application to Minnie Dean}

The issue of appeal arose at the conclusion of the trial's first day, in regard to the admissibility of evidence. The Crown asked for permission to call evidence detailing Minnie's movements in obtaining Eva Hornsby. They intended to prove that the child was also murdered by Minnie; the object of the evidence to show that Dorothy's death was not accidental. ${ }^{84}$ Hanlon objected on the basis that although evidence that Eva Hornsby had died under suspicious circumstances did not in itself prove that Minnie had murdered Dorothy, such evidence could seriously prejudice the case. ${ }^{85}$

During Thomas Hall's trial for the murder of Captain Cain, a similar evidential issue arose. Hall's lawyer opposed the introduction of evidence about the earlier poisoning of Hall's wife Kitty. He argued that evidence of the commission of one crime could not be used to prove the commission of another. ${ }^{86}$ Williams $\mathrm{J}$ decided to admit the evidence but he reserved the point. ${ }^{87}$ This assured consideration of the issue by the Court of Appeal. ${ }^{88}$ After Hall was found guilty, his lawyer argued before the Court of Appeal that evidence of Kitty's poisoning was only admissible after it had first been proved by other evidence that Hall had administered poison to Captain Cain. ${ }^{89}$ The Judges of the Court of Appeal, which included Williams $\mathbf{J}$, agreed and ruled the evidence inadmissible. Thomas Hall's murder conviction was subsequently quashed. This decision was likely influenced by Williams J's assertion that no jury "if they could have excluded from their minds the poisoning of Mrs Hall ... could have convicted on the evidence". 90

Despite his decision in $R v$ Hall, during Minnie's trial, Williams $\mathrm{J}$ held that there was "no doubt" that the evidence around Eva Hornsby was admissible. ${ }^{91}$ This ruling was supported by the 1893

82 Section 413.

83 Jeremy Finn "Development of the Law in New Zealand" in Peter Spiller, Jeremy Finn and Richard Boast (eds) A New Zealand Legal History (2nd ed, Brookers, Wellington, 2001) 75 at 104.

$84 R v$ Dean, above $\mathrm{n} 67$, at 4 .

85 Hood, above n 1, at 167.

86 Peter Graham Vile Crimes: The Timaru Poisonings (Canterbury University Press, Christchurch, 2007) at 124.

87 Hood, above n 1, at 171 .

88 Court of Appeal Act 1882, s 20.

89 Graham, above n 86, at 148

90 At 148 .

$91 R v$ Dean SC Invercargill, 19 June 1895, reported in Otago Daily Times (Dunedin, 20 June 1895) 3 at 3. 
Privy Council decision Makin v Attorney-General for New South Wales. ${ }^{92}$ Sarah and John Makin were convicted of the wilful murder of an adopted infant whose body was found buried in their garden. The case went to the Privy Council on the admissibility of evidence that several other infants had been received by the Makins and found buried in a similar manner. Their Lordships held that the evidence of the other bodies was relevant to the charge. ${ }^{93}$ However, they stated that evidence that the accused had been guilty of criminal acts other than those covered by the indictment is generally inadmissible, unless it bears upon the question of whether the charges were designed or accidental or rebuts a potential defence. ${ }^{94}$

Hanlon accepted it was difficult to argue that the Makin authority did not apply. However, as this was a capital case he asked that Williams J reserve the issue. If this was refused, he wished the objection to be noted. ${ }^{95}$ Williams $\mathbf{J}$ held that the evidence was relevant to the jury because it formed part of the res gestae of events. ${ }^{96}$ On that basis, he did not feel it was his duty to reserve the point. However, in fairness to the prisoner in a capital case, he declined to say the point was frivolous and agreed to take note of the objection. The same evidential issue arose the following day when the Crown asked to call evidence to show that the accused received other infants in her charge, that they disappeared and that the skeleton of one was found buried in her garden. The intention was again to show that Dorothy's death was not an accident. ${ }^{97}$ This was objected to by Hanlon. Williams J refused to reserve the point, but again noted the objection. ${ }^{98}$

Lynley Hood argued that in $R v$ Hall, Williams J, without being asked, assured Hall's lawyer an automatic hearing in the Court of Appeal. In contrast, he placed two distinct obstacles in the way of Hanlon; the need for prior permission from the Attorney-General and permission from the Court of Appeal itself. ${ }^{99}$ While the appeal process in Minnie Dean's case was more difficult than it was for Thomas Hall, this does not mean that due process was not followed. Unlike in $R v \mathrm{Hall}$, when the law was in a more unsettled state, Williams $J$ was faced with strong authority from the Privy Council, which on its face did apply. Furthermore, the legal process had changed since Hall's trial in 1886. Williams J now had the ability to note an objection when he did not feel the point was strong

92 Makin v Attorney-General for New South Wales [1894] AC 57 (PC).

93 At 68.

94 At 65.

$95 R v$ Dean, above $\mathrm{n} 91$, at 3 .

96 At 3.

$97 R v$ Dean SC Invercargill, 20 June 1895, reported in Otago Daily Times (Dunedin, 21 June 1895) 3 at 3.

98 At 3.

99 Hood, above n 1, at 171. 
enough to reserve. ${ }^{100}$ The issue in Minnie Dean's case did ultimately reach the Court of Appeal, where the admissibility of evidence was argued in full at the application stage.

\section{F Hanlon's Address}

\section{Legal procedure}

At the end of the prosecution's case, the defence could declare whether or not it intended to adduce evidence on behalf of the accused. ${ }^{101}$ It was only after reforms in 1889 that the accused could be called as a witness for the defence. ${ }^{102}$ In the event of evidence for the defence being called, the prosecution had the right to reply. ${ }^{103}$

\section{Application to Minnie Dean}

Alfred Hanlon elected not to call Minnie Dean as a witness. By calling no other witnesses, he gave himself the right of final address to the jury. In an impassioned 90-minute speech, Hanlon attempted to persuade the jury that only the evidence relating to Dorothy Edith Carter was relevant and that her death was an accident. ${ }^{104}$ While conceding that it had been proven that Dorothy died between Dipton and Lumsden by an overdose of laudanum administered by Minnie, Hanlon argued that there was no evidence of premeditated murder. Hanlon asked why Minnie would have let her other foster children and members of the public see Dorothy if she wanted to kill her. Would it not have been wiser to kill the child between Bluff and Invercargill? ${ }^{105}$ Hanlon questioned the Crown's dismissal of motive, instead asking why Minnie would want to the kill the child when she had received no money for her and had no security for any future payment. Finally, there were five children living with the Deans at the time of Minnie's arrest. They were well-nourished and educated, with no evidence that Minnie was systematically taking in children for money as the Crown would have the jury believe. ${ }^{106}$ At the close of Hanlon's address, the public gallery exploded with applause. Hanlon had made a clear impact on the crowd, and likely the jury, with one reporter noting that many thought "it not unlikely that a verdict of manslaughter would be returned". ${ }^{107}$

100 Criminal Code Act 1893, s 412(3).

101 Section 401(1).

102 Criminal Evidence Act 1889, s 2.

103 Criminal Code Act 1893, s 401(2).

$104 R v$ Dean SC Invercargill, 21 June 1895, reported in Otago Daily Times (Dunedin, 22 June 1895) 6 at 6.

105 At 6.

106 At 6 .

107 At 6. 


\section{G Judge's Summing Up}

\section{Legal procedure}

After the evidence had been concluded in a criminal trial, it was standard procedure for the judge to sum up the case for the jury. Despite no statutory provision for this procedure, it was a practice uniformly followed for centuries. ${ }^{108}$ Notable 19th century English judge Sir James Fitzjames Stephen described how the judge's position was that of an advisor and a moderator; a role which gave the proceedings of a jury trial "that air of gravity, dignity and humanity ... which ought to make every such court a school of truth, justice and virtue". ${ }^{109}$ While the judge could, and generally did, indicate his opinion, it was to be an opinion which was the result of the evidence laid before him and not of an independent inquiry. ${ }^{110}$ Under the Criminal Code Act 1893, one of the questions of law that could be reserved for the Court of Appeal was "the direction of the judge". 111 This suggests that there was a procedural standard for the judge's summing up that could be subject to judicial scrutiny. However, it is uncertain how practical this appeal provision would be if the appellant was reliant upon the judge in question to reserve or note the point. In all other respects however, "each judge was very much a law unto himself in regard to his summing up". ${ }^{112}$

In response to an ultimately unsuccessful 1894 Bill that proposed to restrain a judge from commenting on the evidence, Williams $\mathrm{J}$ had argued strongly that a judge's remarks were necessary to assist the jury. In an impassioned defence of the judge's role, Williams $\mathrm{J}$ argued that a judge's training "enables him to analyse and disentangle facts and discover fallacies" in order to see justice done. ${ }^{113}$ Williams $\mathrm{J}$ believed that the "less intelligent a jury are, the more likely they are to be influenced, not by reason, but by emotion". ${ }^{114}$ Further, he argued that the proposal would be distinctly against the poor man. The wealthy would be more likely to afford superior counsel who could best take measure of the jury, giving them "in the absence of any counterbalancing influence" an overwhelming advantage. ${ }^{115}$

108 Adams, above n 57, at 780 .

109 James Fitzjames Stephen History of the Criminal Law of England (MacMillan and Co, London, 1883) vol 1 at 574 .

110 James Fitzjames Stephen A General View of the Criminal Law of England (MacMillan and Co, London, $1863)$ at 161 .

111 Section $412(1)$.

112 Adams, above n 57, at 780 .

113 JS Williams Supreme Court Amendment Bill, 1894. Remarks by Mr. Justice Williams on the Proposal to Restrain a Judge in Charging a Jury from Commenting on the Evidence (Conference of Law Societies, Wellington, 1894) at 5.

114 At 5 .

115 At 6. 


\section{Application to Minnie Dean}

Following Hanlon's final address on the third afternoon, Williams $\mathbf{J}$ announced that he would reserve his summing up until the following morning. It was just before five o'clock in the evening and Williams $\mathbf{J}$ stated that he believed it was extremely undesirable that the most important part of the jury's duty should be performed at the end of a long day. ${ }^{116}$ He later admitted that the object of the adjournment was to afford the jury an interval for "calm consideration" after Hanlon's emotional address to the jury. ${ }^{117}$ The following morning, Williams $\mathrm{J}$ summed up strongly against the accused. One reporter commented that his remarks were "evidently directed with the distinct object of counteracting any influence that ... the defence might have been expected to excite on the minds of the jury". ${ }^{118}$ Williams J's summing up was so strong that the same report described that by the time his Honour had finished "there could hardly be any doubt in the minds of any what the verdict would be, however the jury may have been previously influenced". 119

Williams $\mathbf{J}$ began by stressing that the jury needed to take into account the evidence as a whole, and that included the circumstances relating to the disappearance of Eva Hornsby. Williams $J$ then said he believed that adoption was done either as a pecuniary transaction or for the natural love of the child. If it was a business arrangement, which Williams $\mathbf{J}$ implied the adoption was, what could be said if the sum was inadequate? If a poor woman was taking on a child for a low sum, does that not suggest an improper motive ${ }^{120}$ Williams $\mathbf{J}$ proposed this view despite no figures having been presented in court regarding Minnie's adoption fees, which were not unusually low by contemporaneous standards. It appears that Williams J's proposition was based on opinion rather than fact. ${ }^{121}$ In regards to Hanlon's argument that Minnie would want to keep Dorothy alive to receive the money, Williams J concluded that since Dorothy's parents were in Christchurch, they were unlikely to visit the child. Williams $\mathbf{J}$ stressed the importance of the evidence about Eva and the other children. While the death of one child may be innocent, the deaths of two children in similar circumstances strongly suggested that they had been murdered. ${ }^{122}$

In his concluding remarks, Williams $\mathbf{J}$ said that the jury had to determine whether the only reasonable conclusion was that Dorothy Edith Carter's death was intentionally caused. If there was a

$116 R v$ Dean, above $\mathrm{n} 97$, at 3 .

117 W Downie Stewart Portrait of a Judge: Sir Joshua Strange Williams (Whitcombe and Tombes, Wellington, 1945) at 54

$118 R v$ Dean, above n 104, at 6.

119 At 6.

120 At 6.

121 Hood, above n 1, at 181.

$122 R v$ Dean, above n 104, at 6. 
fair doubt, then it was their duty to give the accused the benefit of this doubt. Despite this, Williams $\mathrm{J}$ warned that "phrases such as shadow of a doubt, and so on, are altogether out of the question". ${ }^{123}$ A verdict of manslaughter assumed that the intentions of the person administering the drugs were perfectly honest, and without the slightest intention to do harm. He warned the jury against such a verdict unless it was fully justified. Looking at the evidence before him, Williams $\mathbf{J}$ argued that a manslaughter verdict would "indicate a weak-kneed compromise". ${ }^{124}$ It seemed to him that the issue in this case was whether the accused was guilty of intentionally killing the child or was innocent altogether. $^{125}$

As it is today, culpable homicide not amounting to murder was manslaughter. ${ }^{126}$ It was not contested by the defence that Dorothy Edith Carter died under Minnie's care. By essentially ruling out a manslaughter conviction, Williams $\mathrm{J}$ was directing the jury to find a verdict of murder, even if the defence had raised some serious flaws in the Crown's argument. Criminal procedure in 1895 enabled Williams $\mathbf{J}$ to express his opinion to the jury. However, it appears that Williams $\mathrm{J}$ not only reiterated the main arguments of the Crown and rebutted Hanlon's points, but offered his own interpretations on a number of central issues. When there was already such strong public pressure for a murder conviction, Williams J's direction would have made it very difficult for the jury to reach a manslaughter verdict. It was therefore relatively unsurprising that after just 30 minutes, the jury found Minnie Dean guilty of murder.

\section{COURT OFAPPEAL APPLICATION}

After receiving consent from the Attorney-General, Hanlon's application to appeal Minnie Dean's case was considered by the Court of Appeal in Wellington on 27 July 1895. As with the Hall appeal, Williams J sat on the case, alongside Sir James Prendergast CJ and Richmond, Conolly and Denniston JJ. ${ }^{127}$ As Hanlon was unable to attend, Minnie was represented by Dr Findlay. Findlay proposed to argue the matter fully at application stage, ensuring that Minnie's appeal could not be dismissed before it was heard. ${ }^{128}$ Findlay conceded that the evidence on Eva Hornsby was admissible as it appeared impossible to argue that it was not part of the res gestae. ${ }^{129} \mathrm{He}$ instead argued that the evidence about the other children was inadmissible. The Makin authority would only allow for evidence to rebut a suggestion of accident. The evidence must go to that point rather than

123 At 6

124 At 6.

125 At 6 .

126 Criminal Code Act 1893, s 166.

127 Hood, above n 1, at 188-189.

128 At 189 .

$129 R v$ Dean (1895) 14 NZLR 272 (CA) at 275. 
being used to strengthen the general evidence. Further, the evidence must form a series of similar occurrences. In this case, the evidence of other children was not sufficiently similar. The bodies of four other children were not found and the skeleton was not shown to be that of any child received by the accused. ${ }^{130}$

The application for leave to appeal was unanimously refused by the Court of Appeal. Prendergast CJ interpreted Makin as bearing on cases when there was evidence that the accused earlier received infants for inadequate adoption sums; the inference being that they retained the money and disposed of the child. If, during the trial for the murder of a particular infant, there was proof that the child was received under similar circumstances, such earlier action may be admitted, as it bears upon whether the death was designed or accidental. ${ }^{131}$ Prendergast CJ concluded that there was no doubt of the admissibility of the evidence around the earlier children to prove that the death of Dorothy Carter was designed, and not accidental. ${ }^{132}$ In addition to agreeing with the Chief Justice, Williams $\mathbf{J}$ took the opportunity to defend the Court of Appeal's decision in $R v$ Hall by asserting that it did not conflict with Makin because, apart from the evidence objected to, there was no evidence that Hall administered poison to Captain Cain. ${ }^{133}$

\section{SENTENCING AND EXECUTION}

\section{A Legal Procedure}

The early procedures in New Zealand for dealing with convicted offenders were highly derivative and the penalties were all taken from Britain. ${ }^{134}$ Between 1840 and 1961, except for nine years from 1941 until 1950, the mandatory sentence for a murder conviction was death. ${ }^{135}$ Whether the death sentence would be carried out depended upon the Executive Council, who could advise the Governor to exercise the Royal prerogative of mercy. ${ }^{136}$ One of the key debates about the early penal system was whether hangings should be public or private affairs. ${ }^{137}$ Initially executions were public and the first eight men executed were publicly hanged in Auckland and Wellington. ${ }^{138}$ In

130 At 275 .

131 At 282 per Prendergast CJ.

132 At 282 per Prendergast CJ.

133 At 184 per Williams J.

134 Finn, above n 83, at 104

135 Sherwood Young Guilty on the Gallows: Famous Capital Crimes of New Zealand (Grantham House Publishing, Wellington, 1998) at 7 .

136 At 9 .

137 Campbell, above n 2, at 376.

138 Young, above n 135, at 7. 
1858 a Bill was introduced into the Legislative Council to make executions private, with supporters arguing that public executions had a degrading and demoralising tendency. Opponents believed that it would be dangerous to have private executions "in a colony where a large Native population was found" as the shock of public executions were "calculated to have a powerful effect on men's minds". ${ }^{139}$ The Bill ultimately passed and the Execution of Criminals Act 1858 required hangings to be held within the confines of a gaol, or another private place that was appropriately appointed. ${ }^{140}$

\section{B Application to Minnie Dean}

After Minnie Dean's leave to appeal was denied, the Executive Council, led by Premier Seddon, declined to commute Minnie's sentence. ${ }^{141}$ This decision was supported by the press, with one columnist writing "we cannot doubt that the decision was a right and proper one ... there was no redeeming feature in the case - nothing at all that could be urged as a plea for mitigation in the sentence". 142

It was entirely open for the Executive Council not to commute Minnie's death sentence. Yet the decision to subject a woman to capital punishment was a radical move and one that had been avoided in earlier female murder trials. In February 1883, the body of a four-year-old girl was found washed up from the Wanganui River during a flood. Her mother, 23-year-old Phoebe Veitch, was found guilty of her murder in the Wanganui Supreme Court and sentenced to death. However, after a jury of matrons held Phoebe to be pregnant, her sentence was commuted to life imprisonment. A week later, Phoebe wrote a confession admitting her guilt. ${ }^{143}$ In 1891 Anna Flanagan and her mother Sarah had their death sentences for the brutal murder of Anna's child commuted to life imprisonment by the Executive Council. ${ }^{144}$

In general, authorities and juries showed considerable sympathy towards mothers charged with the death of their child, even when there was evidence of violence. ${ }^{145}$ In 1866 Sir James Fitzjames Stephen wrote how there was much compassion for mothers charged with infanticide as they were "often in extreme distress, and in excitement which may almost amount to temporary madness". ${ }^{146}$

139 Campbell, above n 2, at 376.

140 Section 1.

141 Hood, above n 1, at 191.

142 "The Week" Otago Witness (Dunedin, 8 August 1895) at 27.

143 Dalley, above n 7, at 66.

144 "Auckland March 13" North Otago Times (Dunedin, 14 March 1891) at 2.

145 Alison Clarke Born into a Changing World: Childbirth in Nineteenth-Century New Zealand (Bridget Williams Books, Wellington, 2012) at 232.

146 James Fitzjames Stephen "The Law of Murder" (1866) 26 London Quarterly Review 428 at 450. 
Historian Alison Clarke identified 98 other 19th century cases where people appeared before New Zealand courts for their involvement in the death of a newborn child. All but four of these involved charges against the mother. However, only one resulted in a murder conviction and it was the father who was convicted. ${ }^{147}$

The Victorian contempt of baby-farming was likely a significant factor behind Minnie becoming the only New Zealand woman to be executed. As an alleged baby-farmer, Minnie was seen as the ultimate villain who deserved a harsher punishment than suffering mothers charged with the death of their children. Despite judicial sympathy towards mothers, many people did not support the more lenient sentences. The Executive Council likely remembered the intense public outrage after the Flanagans' sentences were commuted two years earlier. ${ }^{148}$ The crime was especially violent and Sarah attracted less sympathy than many other mothers because she was older and this was not her first child. ${ }^{149}$ It was therefore relatively unsurprising that the Executive Council declined to grant Minnie Dean mercy.

Carrying out an execution was often a matter of urgency for authorities as delays could provoke public outcries for clemency. ${ }^{150}$ Minnie's execution took place in the courtyard of Invercargill Prison, on the morning on Monday 12 August 1895. Present were the sheriff, the doctor, the Magistrate and select press reporters. ${ }^{151}$ The following day, the details of the execution were described in newspapers around New Zealand. One reporter wrote of how struck he was by Minnie Dean's "dignified carriage and bearing". ${ }^{152}$ On the scaffolding, the sheriff asked if Minnie Dean had anything to say, to which she replied, "I have nothing to say, except that I am innocent". At two minutes past eight, the bolt was drawn and the body dropped out of sight to all except those who had ascended the scaffolding with her. ${ }^{153}$

\section{CONCLUSION}

The purpose of this article has been to determine whether correct criminal procedure was followed during the 1895 murder trial and sentencing of Minnie Dean. This exercise has involved an analysis of the facts against 19th century criminal procedure and a comparison of Minnie Dean's trial and sentence to contemporaneous criminal cases. Acknowledgment must be given to the

147 Clarke, above n 145, at 231.

148 Hood, above n 1, at 191-192.

149 Clarke, above n 145, at 240.

150 Hood, above n 1, at 194.

151 "The Winton Murder Case" Evening Post (Wellington, 12 August 1895) at 3.

152 "The Winton Child Murder" Otago Daily Times (Dunedin, 13 August 1895) at 3.

153 At 3 . 
extensive work conducted by historian Lynley Hood in Minnie Dean: Her Life and Crimes. ${ }^{154}$ Hood questioned a number of the presumptions that have prevailed around Minnie Dean and argued that Minnie was not the heartless baby-farmer as traditionally perceived. Hood also gave a fairly critical account of Minnie's treatment during the criminal trial process.

While it can appear that Minnie Dean's trial was merely a formality, this article has concluded that from a strict 1895 legal standpoint, correct criminal procedure was generally followed. During the pre-trial proceedings, the coroners' juries were expressly entitled to state whether they believed Minnie had killed the infants. Although the intensive press coverage and the local hostility towards Minnie suggest that her trial should have changed location, it is unlikely that a transfer would have resulted in a substantially fairer trial. Minnie Dean was not tried before a jury of her peers, with 12 men from the local community responsible for her fate. Despite appearing unrepresentative from a modern perspective, this was correct 19th century jury procedure. In 1895, appeals were not an automatic right, so it was legitimate for Williams J not to reserve Hanlon's objection to evidence about Eva and the other foster children. Despite differing from his ruling in $R v$ Hall, the Makin case was strong authority for Williams $\mathbf{J}$ holding the evidence admissible. The most contentious aspect of the trial was Williams J's summing up. Judges had the power to express their opinions, despite propositions to limit their ability. However, it appears that Williams J went beyond the scope of his power by offering his own interpretation of the evidence and essentially ruling out the possibility of a manslaughter conviction. In terms of sentencing, the Executive Council was under no obligation to grant Minnie Dean mercy. However, it is likely that their decision was largely influenced by the public climate against baby-farming and the outrage after earlier infanticide sentences were commuted.

Minnie Dean's trial offers a fascinating insight into the sensationalism of 19th century New Zealand criminal trials. While correct procedure was generally followed, when comparing Minnie Dean's case to that of an affluent male such as Thomas Hall, it is evident that Minnie was not granted the same leniency that was available to others. The New Zealand press and public collectively demanded the ultimate punishment for the notorious Southland baby-farmer and largely for that reason Minnie Dean was afforded no procedural clemency. 